\title{
Effects of glyphosate on hepatic tissue evaluating melanomacrophages and erythrocytes responses in neotropical anuran Leptodactylus latinasus
}

\author{
Juan Manuel Pérez-Iglesias ${ }^{1,3}$ • Lilian Franco-Belussi ${ }^{2}$ - Liliana Moreno ${ }^{1}$ • \\ Susana Tripole $^{1} \cdot$ Classius de Oliveira $^{2} \cdot$ Guillermo Sebastián Natale $^{1,3}$
}

Received: 5 September 2015 / Accepted: 20 January 2016 / Published online: 9 February 2016

(C) Springer-Verlag Berlin Heidelberg 2016

\begin{abstract}
Glyphosate (GLY) is the most used herbicide worldwide and its effects on anurans are well known. Pollutants can cause physiological and morphological effects. Therefore, this study evaluated the effects of GLY on hepatic melanomacrophages as a response to environmental stressors. Three treatments were exposed to different concentrations of pure GLY $\left(100,1000\right.$, and $10,000 \mu \mathrm{g} \mathrm{g}^{-1}$, respectively), and there was also a control group. After the experimental time, liver and blood were analyzed. Melanomacrophages (MMCs) were located between the hepatocyte cordons, close to sinusoids. GLY increased the melanin area in MMCs of Leptodactylus latinasus exposed since lowest concentration until highest concentration. GLY also changed the occurrence of hepatic catabolism pigments into melanomacrophages and erythrocyte nuclear abnormalities; therefore, it can interfere with the hepatic metabolism. In conclusion, GLY promotes
\end{abstract}

Responsible editor: Thomas Hutchinson

Electronic supplementary material The online version of this article (doi:10.1007/s11356-016-6153-z) contains supplementary material, which is available to authorized users.

Classius de Oliveira

classius@ibilce.unesp.br

1 PROICO 9401, Área Zoología, Facultad de Química, Bioquímica y Farmacia, Universidad Nacional de San Luis, Chacabuco 917, San Luis 5700, Argentina

2 Department of Biology, São Paulo State University (UNESP), IBILCE, Rua Cristóvão Colombo, 2265, Jardim Nazareth, São José do Rio Preto 15054-000, São Paulo, Brazil

3 Centro de Investigaciones del Medio Ambiente, Departamento de Química, Facultad de Ciencias Exactas, Universidad Nacional de La Plata, CONICET, La Plata, Argentina alterations in the hepatic tissue and erythrocyte nuclear abnormalities. Furthermore, MMCs may be useful as morphological responses of GLY effects.

Keywords Glyphosate $\cdot$ Melanomacrophages $\cdot$ Melanin · Hemosiderin · Morphological responses · Genotoxic effects

\section{Introduction}

Glyphosate (GLY) (N-[phosphonomethyl] glycine; CAS no. 1071-83-6) is a weak organic acid that inhibits the shikimic acid biosynthesis pathway in plants. Glyphosate has become the most commonly used herbicide in Argentina and elsewhere in the world since the 1990s. There is a wide range of formulations for application in agriculture, forestry, industry, and home sectors (Giesy et al. 2000; Arregui et al. 2004; Reboratti 2010; Struger et al. 2008).

Only a part of the amount of pesticides used in agriculture reach the target, the remainders flow into the ground, via air or water, contaminating a variety of microhabitats, including lakes and ponds in the vicinity of crops where anurans live and breed. Once this contamination takes place in a water body, an acute and/or chronic exposure affects all life stages (eggs, tadpoles, and adults) of anurans. The accumulation of such pesticides in the environment can cause adverse effects to the anuran health (Harris et al. 1998; Greulich and Pflugmacher 2003; Relyea et al. 2005; Rohr and Crumrine 2005; Gurushankara et al. 2007).

The increasing use of pesticides is regarded as one of the main factors responsible for the dramatic decline in anuran populations in the past decades (Blaustein and Wake 1990; Davidson et al. 2002; Blaustein et al. 2003; Sparling et al. 2010). Anurans are widely used as bioindicators of environmental quality due to some special traits (e.g., their permeable 
skin, position in trophic webs, shell-less eggs, exposed embryogenesis, free-living aquatic larvae, dependence upon two environments throughout their life history, and a narrow home range (Blaustein and Wake 1990; Blaustein et al. 1994, 2003; Stebbins and Cohen 1995). Several studies have used anurans to evaluate the effects of GLY at different ecological levels (Mann and Bidwell 1999; Giesy et al. 2000; Govindarajulu 2008; Relyea and Jones 2009; Jones et al. 2010; Fuentes et al. 2011; Lajmanovich et al. 2011; Moore et al. 2012; Güngordü 2013; Meza-Joya et al. 2013; Wagner et al. 2013; Annett et al. 2014).

Pesticides can negatively affect amphibian individuals and populations, specifically their survival. They alter the larval growth and development rates; change morphology, physiology, and behavior; and induce genetic damage to the DNA, thus reducing the reproductive output (Carey and Bryant 1995; Jha 2008; Sparling et al. 2010; Gonçalves et al. 2014). Moreover, environmental pollutants or stressors are known to affect the immune system of amphibians (Christin et al. 2004; Jantawongsri et al. 2013). It is known that the cells containing pigments present in hematopoietic organs, e.g., melanomacrophages (MMCs), play a role in the immunological response and the detoxification of pollutants (Agius 1981; Agius and Roberts 2003; van der Oost et al. 2003; FrancoBelussi et al. 2013) and aggressive phagocytic cells that readily consume fungi, bacteria, parasites, mycobacteria, foreign bodies, and involved on hemocateresis by phagocytosis on cell debris, including hemoglobin breakdown products (Rund et al., 1998; Campbell 2015). MMCs produce and store three pigments: melanin, hemosiderin, and lipofuscin (Agius 1981; Agius and Roberts 2003; Jordanova et al. 2008). Melanin can absorb and neutralize free radicals and other toxic substances derived from the cell metabolism (Agius and Roberts 2003). MMCs appear to synthesize melanin, which is a protective pigment capable of scavenging free radicals and neutralizing cations, thereby protecting tissues from cytotoxic damage (Barni et al. 1999; Campbell 2015). Lipofuscin is produced via oxidative polymerization of polyunsaturated fatty acids, which accumulate as the result of a deficient diet (Pickford 1953). Lastly, hemosiderin is an intermediate metabolic product, generated during the recycling of components in the erythropoiesis (Kranz 1989). In recent years, there has been increasing interest on the possible role of melanin in MMCs as a scavenger of free radicals (Rozanowska et al.1999; Loumbourdis 2007) and other toxic substances. Studies in anurans showed that the exposure to different environmental pollutants such as heavy metals (cadmium) or insecticides (chlorpyrifos) increased MMC's proliferation in the liver, following a specific pattern (Loumbourdis and Vogiatzis 2002; Păunescu et al. 2010). Adding to that, Jantawongsri et al. (2013) indicated that an increase in MMCs number and area could be associated with environmental pollutants. Whereas Herberg and Wallin
(2010) have shown that Roundup formulations affect the intracellular transport of melanin vesicles (e.g., melanosomes) into skin pigmented cells cultured (e.g. melanophores) of Xenopus by decrease of $\mathrm{pH}$ and intracellular $\mathrm{Ca}^{2+}$ balance, as well as the morphology and integrity of the cytoskeleton.

In the other hand, previous reports demonstrated that GLY is geno- and cytotoxic herbicide by the induction of micronucleus (MNs) in circulating erythrocytes from amphibian tadpoles as a consequence of GLY treatments (Meza-Joya et al. 2013; Yadav et al. 2013; Bosch et al. 2011; Clements et al. 1997). The exact mechanism of the genotoxic effects of glyphosate or its formulations is not known (Yadav et al. 2013). These authors reported that formulation of glyphosate used in his works has a clastogenic effect in anurans, agreeing with the report of Clements et al. (1997). The MNs assay is employed worldwide as genotoxic bioassay to detect small chromosomal fragments, i.e., acentric fragments and chromatid fragments, induced by clastogens or vagrant chromosomes produced by aneugens (Fenech, 2007; OECD, 2007). Despite the lack of knowledge about the mode of action of GLY, some authors mentioned that elevated levels of reactive oxygen species and/or depressed antioxidant defenses may result in DNA oxidation and increased steady-state levels of unrepaired DNA, which is a well-known process underlying genotoxicity, in particular in the context of environmental genotoxicants (Azqueta et al., 2009).

Since MMCs acts in the detoxification of pollutants and GLY can alter melanin vesicles transport in skin pigmented cells; we hypothesized that the melanin present in liver melanomacrophages should increase after endogenous administration of pure glyphosate in Leptodactylus latinasus by increased liver detoxification action that produce free radical and this radicals can be neutralized by melanin. The effects of pure glyphosate (administered intraperitoneally) in hepatic MMCs of L. latinasus were evaluated in this study for the first time by assessing the changes in the melanin pigmented area occupied on melanomacrophages cells, beyond the area occupied by catabolic substances (e.g., hemosiderin and lipofuscin) and the presence of MNs and other nuclear abnormalities in erythrocytes were evaluated since geno- and cytotoxic effects of GLY is known. Then, we aim to describe systemic effects of GLY in anuran particularly at histological level.

\section{Materials and methods}

\section{Chemicals}

For the bioassays, $99 \%$ purity grade GLY (CAS 1071-83-6) was kindly provided by GLEBA S.A., Argentina. The historesin used in bioassays came from the Leica Historesin 
embedding kit. All other chemicals and solvents of analytical grade were purchased from Sigma-Aldrich Chemical Co.

\section{Anuran specie}

Leptodactylus latinasus (Jiménez de la Espada, 1875), is a medium-sized anuran $(28-40 \mathrm{~mm})$ dispersed in diverse environments between 0 and $600 \mathrm{~m}$ above sea level (i.e., coastal, Pampean grasslands, agroecosystems) throughout Argentina. L. latinasus lives in holes and lays eggs in a foam nest where tadpoles begin their development and emerge when it is inundated by rains or overflowing brooks. The primary route of exposure to pollutants in agricultural habitats is via skin contact with soil or water, direct application or ingestion of insects. Populations of this species are stable, ranked as nonthreatened (Vaira et al. 2012; IUCN, 2013), and are easily maintained under lab conditions.

\section{Source of organisms}

Specimens of $L$. latinasus were collected from a temporary and unpolluted environment, free of agricultural practices, during breeding season in Argentina outside the city of $\mathrm{La}$ Plata, Buenos Aires Province ( $35^{\circ} 0012^{\prime \prime}$ S, $57^{\circ} 5206^{\prime \prime}$ W). All specimens were collected with the permission of the Flora and Fauna Direction from the Buenos Aires Province (code22500-22339/13). Adult males of L. latinasus $(N=20)$ were collected and transported to the laboratory, and then were weighed (weight average, $3.58 \mathrm{~g}$ ) and measured a snout-vent length (average, $33.61 \mathrm{~mm}$ ), posterior acclimated to $16: 8-\mathrm{h}$ light/dark cycles in aquaria at $25{ }^{\circ} \mathrm{C}$, and then transferred to $2800-\mathrm{cm}^{3}$ glass containers with water. The acclimation period lasted 7 days without food (temperature, $25.0 \pm 1{ }^{\circ} \mathrm{C}$; photoperiod 16:8 h).

\section{Acute exposure bioassay}

Experiments for toxicity assessment were performed using four treatments ( $N=5$ per treatment): control (received only Ringer's solution) and 100, 1000, and 10,000 $\mu \mathrm{g} / \mathrm{g}$ of $99 \%$ GLY. For each treatment, technical-grade GLY was dissolved in amphibian Ringer's solution ( $125 \mathrm{nM} \mathrm{NaCl}, 3 \mathrm{nM} \mathrm{KCl}, 10$ $\mathrm{nM} \mathrm{CaCl}_{2}, 1$ L TRIS buffer; Sigma-Aldrich). Treatments were administered via intraperitoneal injection (IP) with a singledose (e.g., $1 \mu \mathrm{L} / \mathrm{g}$; Wright 2006; McComb et al. 2008). These concentrations were adapted from subchronic toxicity studies in mammals (Williams et al. 2000), and based on maximum GLY solubility where no effects were detected and a logarithmic scale was applied to make a screening effect. After the treatment, each organism was kept separately in a glass container with water, and without food during the experimental time (e.g., 48 h).

\section{Specimen processing}

After $48 \mathrm{~h}$ from the initial acute exposure, the specimens from each treatment were weighed $(0.001 \mathrm{~g}$ precision scale) and measured with a digital caliper $(0.01 \mathrm{~mm}$ precision $)$. All specimens were anesthetized, euthanized by freezing, and dissected according to directives and protocols detailed in the Guide for Care and Use of Laboratory Animals (National Research Council, 2011).

\section{Sample processing for histological analysis}

The liver of each experimental organism was extracted, weighed, and placed into Karnovsky fixative solution (0.1 M Sörensen phosphate buffer, phosphate buffer $\mathrm{pH} 7.2$ with $5 \%$ paraformaldehyde and $2.5 \%$ glutaraldehyde) for $24 \mathrm{~h}$ at $4{ }^{\circ} \mathrm{C}$ for further processing. For the histological processing, each liver sample was washed with distilled water, dehydrated in an alcohol series, and embedded in historesin. Afterwards, random $2-\mu \mathrm{m}$-thick sections ( $\sim 65$ sections of each liver) were obtained using a Leica RM 2265 microtome. Approximately 20 liver sections were mounted per slide, totaling to three slides per animal for morphological description and pigment quantification.

The first slide with the liver sections was stained with hematoxylin-eosin for histopathologic analyses and melanin quantification. The second slide was incubated for $15 \mathrm{~min}$ in Schmorl's solution for catabolic pigments to determine lipofuscin. The third slide was incubated during $15 \mathrm{~min}$ in acidic ferrocyanide, followed by staining with solutions of neutral red and eosin for hemosiderin detection. After the staining, histological sections were observed under a Leica DM4000 B microscope with an image capture system (Leica DFC 280).

The analysis of histopathological lesions was carried out by evaluating: hypervascularization (congestion), enlargement of sinusoids, vacuolization in hepatocytes, hemorrhage, and necrosis in hepatocytes according to Cakıc1 (2015). For these analyses, we used ten histological sections. To pigment analyses, 25 micrographs for each staining per animal were analyzed using image analysis system software (Image Pro Plus 6.0, Media Cybernetics, Inc.). The area occupied by each pigment was quantified as melanomacrophages (melanin, hemosiderin, and lipofuscin) based on the different staining intensity, similarly to the method used by Santos et al. (2014) to quantify the area occupied by melanin-containing cell in liver.

\section{Micronuclei and other erythrocytes nuclear abnormalities}

Slides blood was confectioned and micronuclei assay was performed by fixation with cold methanol $\left(4{ }^{\circ} \mathrm{C}\right)$ for $20 \mathrm{~min}$ and then stained with Giemsa solution $(5 \%)$ for $12 \mathrm{~min}$. The frequency of MNs was determined in peripheral mature 
erythrocytes after $48 \mathrm{~h}$. Other erythrocytic nuclear abnormalities were blind-scored from 1000 erythrocytes per experimental point from each experiment at $\times 1000$ magnification. The presence of other nuclear abnormalities in mature erythrocytes was assessed according to the procedures of Lajmanovich et al. (2014) with minor modifications by determining the frequency of the following nuclear lesions: notched nuclei (NN), i.e., nuclei with vacuoles and appreciable depth into a nucleus without containing nuclear material; blebbed nuclei (BL), i.e., cells with one nucleus presenting a relatively small evagination of the nuclear membrane which contains euchromatin; and erythroplastids (EPs), i.e., anucleated forms of circulating red blood cells. Erythrocytes were analyzed, and data were expressed in total number of micronucleus per 1000 cells. Blood analysis was conducted in accordance with Perez Iglesias et al. (2014).

\section{Statistical analyses}

To estimate the effect of the treatments (glyphosate exposure, predictor variable) on histopathological lesions, area occupied by each pigment (melanin, hemosiderin, and lipofuscin) and on the presence of MNs and others nuclear abnormalities (response variables), a one-way analysis of variance (ANOVA) with Tukey test was performed (Zar 2010). Data were visually inspected for checking the assumptions of homogeneity of variance and normality. Then, data were log transformed to meet assumptions. The relationship between area occupied by each pigment, presence of $\mathrm{MNs}$, and others nuclear abnormalities with glyphosate concentrations were evaluated by simple linear regression and correlation analyses. Tests of significance of the regression and correlation coefficients were performed following Zar (2010). Analyses were performed using the R software v. 2.11.1 (R Core Team 2010).

\section{Results}

\section{Liver histopathological analyses}

In normal condition, liver tissue presents hepatocytes in cordons surrounded by sinusoids, and melanomacrophages (Fig. 1, S1). Histopathological lesions were observed in the largest concentration of glyphosate used (GLY 10, $\left.000 \mu \mathrm{g} \mathrm{g}^{-1}\right)$. In the highest GLY concentration were observed increased of vascularization (e.g., hypervascularization) and vacuolization of hepatocyte cytoplasm $(p<0.001$; Fig. 1). In lower concentrations of GLY (e.g., GLY $100 \mu \mathrm{g} \mathrm{g}^{-1}$ and GLY $1000 \mu \mathrm{g} \mathrm{g}^{-1}$ ) histopathological lesions were detected in low frequencies but these are not significant with respect to control $(p>0.05)$.

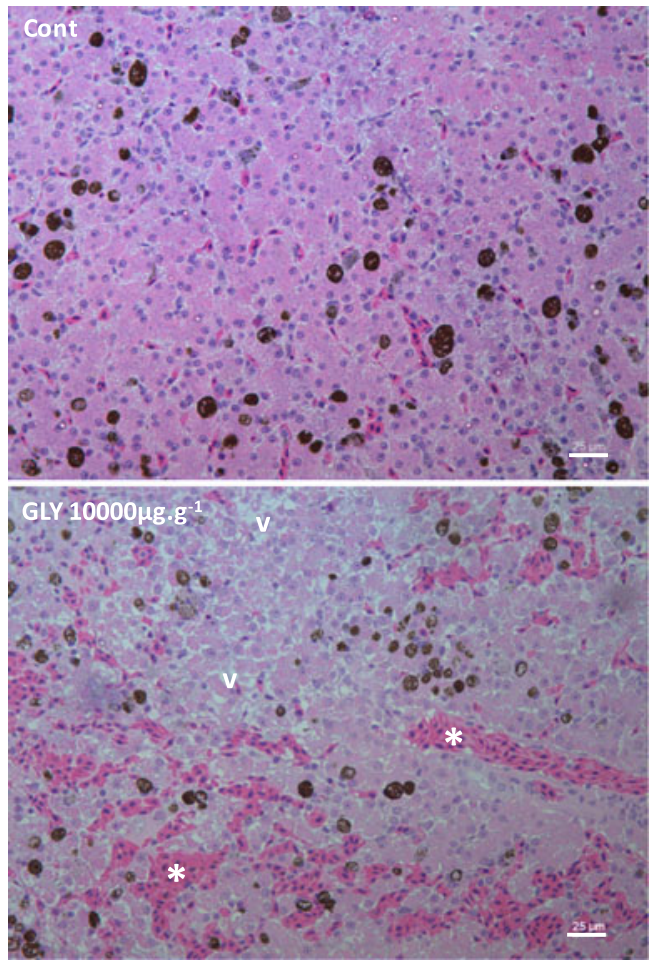

Fig. 1 Histological sections of liver of Leptodactylus latinasus showing normal tissue of control group (Cont) and histopathological alterations in animals treated with glyphosate in high concentration ( GLY $10000 \mathrm{\mu g} \mathrm{g}^{-1}$ ). After GLY exposure is observed, hypervascularization (asterisk) and vacuolization of hepatocyte cytoplasm (v). Staining $=$ hematoxylin-eosin. Bars $=25 \mu \mathrm{m}$

\section{Pigment composition in melanomacrophages}

MMCs were located between the hepatocyte cordons, close to sinusoids. MMCs are large and rounded cells with melanin granules in their cytoplasm (Fig. 2). The amount of melanin, hemosiderin, and lipofuscin are distinct into $\mathrm{MMCs}$ $(p<0.001$, Fig. 2). Melanin was significantly higher $\left(5045 \mu^{2}\right)$ in the MMCs of L. latinasus, followed by hemosiderin $\left(3038 \mathrm{\mu m}^{2}\right)$ and lipofuscin with lowest amount into MMCs $\left(2392 \mu \mathrm{m}^{2}\right)$.

\section{Pigment quantification in MMCs after GLY exposure}

The one-way ANOVA test showed high statistically significant increment $(p<0.001)$ in the MMCs melanin area of L. latinasus exposed to the 100, 1000, and $10,000 \mu \mathrm{g} \mathrm{g}^{-1}$ GLY treatments (Fig. 3). Conversely, one-way ANOVA test showed high statistically significant decreased hemosiderin treated with 100,1000 , and $10,000 \mathrm{\mu g} \mathrm{g}^{-1}$ GLY in the MMCs of L. latinasus $(p<0.05)$. Furthermore, the MMCs lipofuscin area increased significantly $(p<0.001)$ in L. latinasus while in $100 \mu \mathrm{g} \mathrm{g}^{-1}$ GLY treatment (Fig. 3). Therefore, melanin, hemosiderin, and lipofuscin are responsive to $100 \mu \mathrm{g} \mathrm{g}^{-1}$ GLY treatments. 
Fig. 2 Histological sections of liver of Leptodactylus latinasus showing melanomacrophages (asterisk) located between hepatocytes $(H)$, associated with hepatic sinusoids $(S)$.

Melanomacrophages posses rounded shape (asterisk) and besides melanin (asterisk), posses hemosiderin (arrow) and lipofuscin (arrowhead). Left panel show control group (Cont) and right panel show animals treated with $100 \mu \mathrm{g} \mathrm{g}^{-1}$ $\left(\right.$ GLY100 $\left.\mu \mathrm{g} \mathrm{g}^{-1}\right)$. In animals treated, an increase of melanin and lipofuscin and decrease of hemosiderin is observed. Staining $=$ hematoxylin-eosin $(\mathbf{a}-\mathbf{c})$,

Ferrocyanide acid solution $(\mathbf{d}-\mathbf{f})$, Schmorl's solution $(\mathbf{g}-\mathbf{i})$. Bars $\mathbf{a}$, $\mathbf{c}, \mathbf{d}, \mathbf{f}, \mathbf{g}, \mathbf{i}=25 \mu \mathrm{m} . \mathbf{b}, \mathbf{e}$, $\mathbf{h}=5 \mu \mathrm{m}$
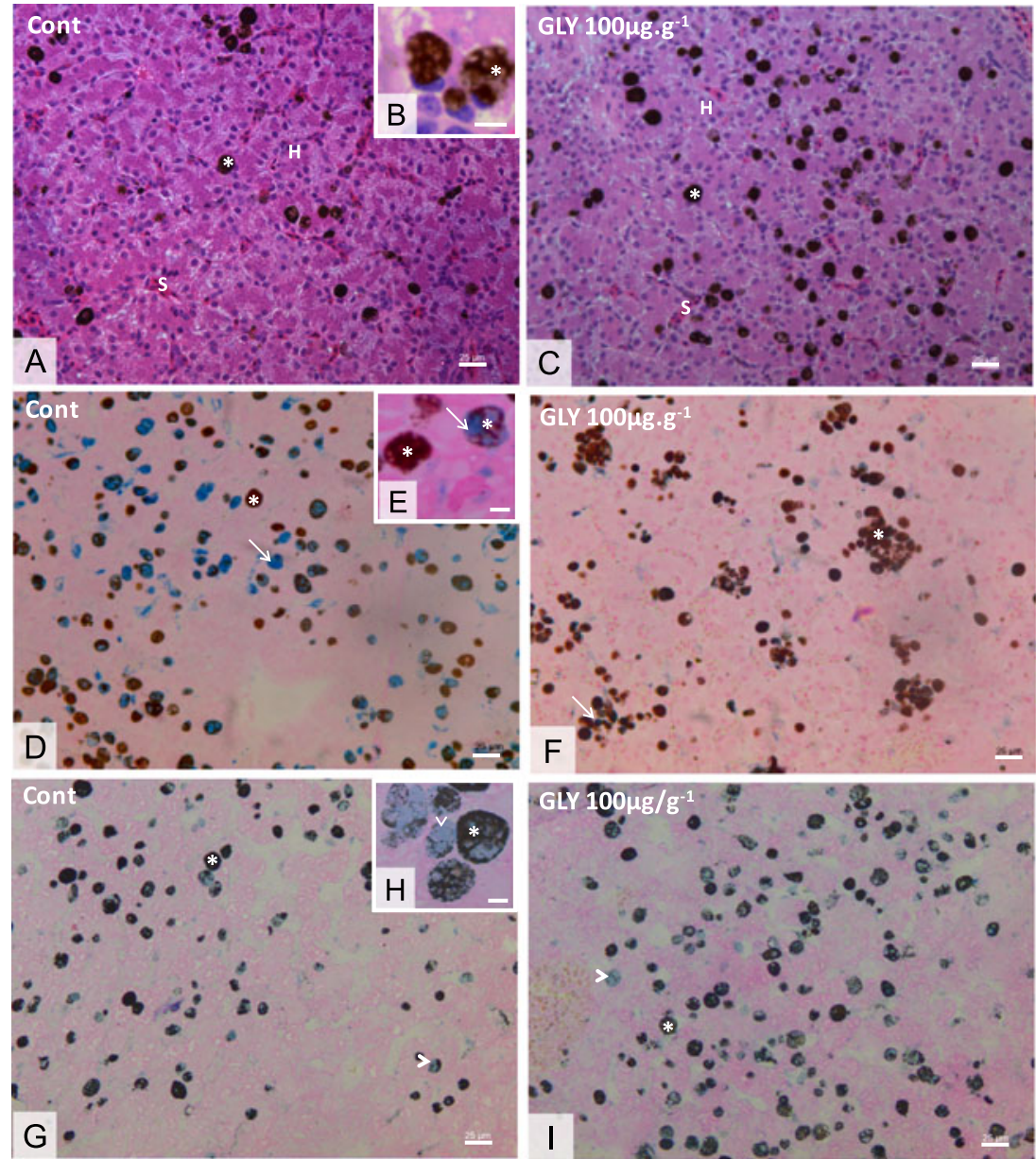

\section{Relationship between pigments in MMCs and GLY exposure}

A regression and correlation analysis showed a significant concentration-dependent increase between melanin on MMCs following treatment with GLY $(r=0.37, p<0.0001)$.
On the other hand, it showed no relationship between GLY concentration and the area occupied by hemosiderin and lipofuscin in MMCs on liver of L. latinasus ( $p>0.05$ ), after $48 \mathrm{~h}$ of exposure.

When comparing three substances in the same experimental condition, we observed a positive correlation $(p<0.05)$
Fig. 3 Differences in pigmented areas of melanin, hemosiderin, and lipofuscin into melanomacrophages of Leptodactylus latinasus. Cont control group; GLY 100, 1000, and $10,000 \mu \mathrm{g} \mathrm{g}^{-}$animals administered 100,1000 , and $10,000 \mu \mathrm{g} \mathrm{g}^{-1}$ of pure glyphosate, and analyzed after 48 h. $N=5$ per treatment. Asterisk show statistical differences between the experimental concentration and the control group for the same substance. ${ }^{*} p<0.05 ;{ }^{* *} p<0.001$

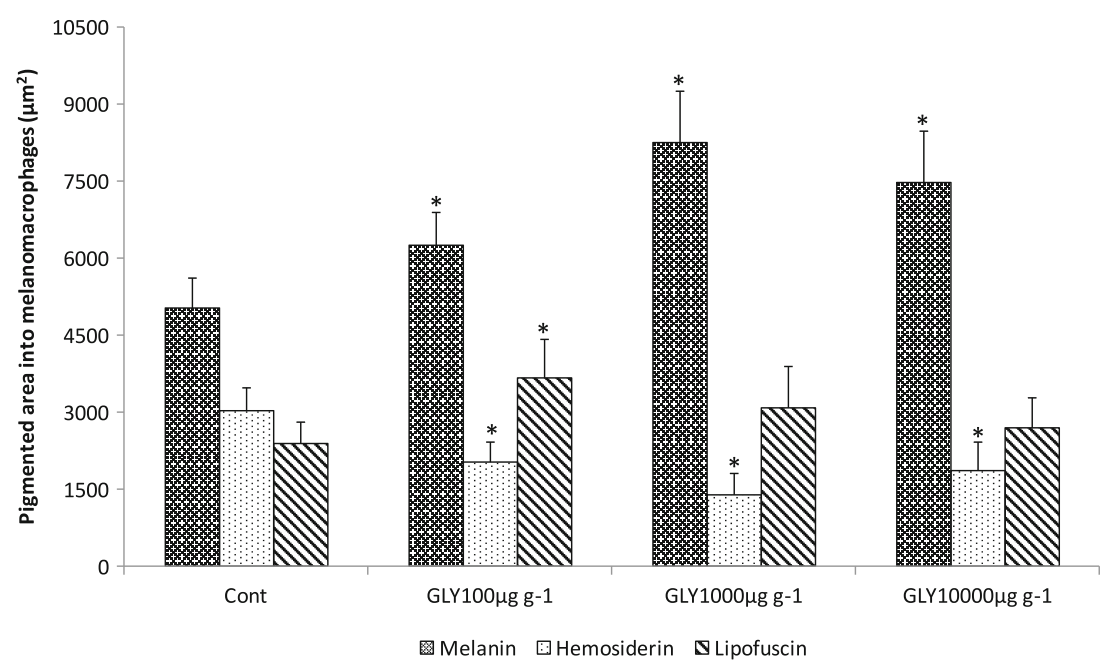


between area of melanin and lipofuscin in GLY $100 \mu \mathrm{g} \mathrm{g}^{-1}$ where both substances increased (Fig. 3). In addition, melanin and hemosiderin posses an inverse correlation in GLY $1000 \mu \mathrm{g} \mathrm{g}^{-1}(p<0.05)$, and catabolic substances (e.g., hemosiderin and lipofuscin) show inverse correlation in GLY $100 \mathrm{~m} \mathrm{~g} \mathrm{~g}^{-1}(p<0.05)$, when hemosiderin decreases while melanin and lipofuscin increases (Fig. 3).

\section{Micronuclei and other erythrocytic nuclear abnormalities}

One-way ANOVA results showed a significant increase of MNs in L. latinasus exposed to glyphosate $(p<0.01)$. Particularly, the increase occurs in frogs exposed to $100 \mu \mathrm{g} \mathrm{g}^{-1}$ GLY $(p<0.05$; Table 1). Furthermore, analysis EPs also shows a significant increase $(p<0.01)$ at 10 , $000 \mu \mathrm{g} \mathrm{g}^{-1}$ GLY (Table 1). No correlation was observed between the micronuclei and GLY concentrations $(p>0.05)$.

\section{Discussion}

This study shows for the first time the effect of glyphosate (GLY) on the histopathologic lesions and on the three hepatic pigments found in the liver MMCs of adult anurans (i.e., melanin, hemosiderin, and lipofuscin). Particularly, GLY increased the melanin and decrease hemosiderin area in the liver MMCs of L. latinasus. This study reports that GLY alters differently the pigmentation response in the hepatic MMCs on L. latinasus which has intense activity during spring and winter. Despite this, further studies on neotropical species are required that can be associated response of MMCs with environmental changes and physiological characteristics of each species, considering the broad lifestyle in this region. In this sense, an increase on pigments of MMCs in fish (Pascoli et al. 2011) and anurans (Franco-Belussi et al., 2013), at pesticide concentrations, was linked to a protective function and detoxification function against GLY.

The decrease in the area of catabolic pigments in MMCs is associated with a reduction in phagocytic activity (Bucke et al. 1992; Fenoglio et al. 2005). The increase registered in lipofuscin area correlated with melanin, at lowest concentration of GLY, points to an increase of oxidative polymerization products, which might be related to a response against melanin free radicals. On the other hand, considering that hemosiderin is an intermediate metabolic product generated during the recycling of components in the erythropoiesis, decrease of this pigment to GLY exposure can be related with damages in normal activities of iron recycling and hepatic catabolic process. In other words, the response of MMCs on liver in this case can be associated with a process of detoxification and renewal of damaged cells. In this sense, physiology and fitness on anurans exposed to pesticides would be compromised. In addition, we observed increased of MNs and eritroplastids after GLY exposure. Decreased hemosiderin in all concentrations of GLY could be related to a deficiency of the liver to perform the function of hemocateresis so the capacity of the organ is unable to remove damaged erythrocytes. Consequently, damaged cells remain in circulation as evidenced by the presence of MNs and EPs in individuals exposed to GLY. Particularly, the increase of the presence of EPs, may represent a particular device for increasing oxygen transport efficiency, particularly in conditions of water pollution (i.e., with pesticide residues) by improving the cell surface/volume ratio like Barni et al. (1999) have mentioned. Genotoxic effects of pesticides like GLY in frogs are widely studied (Clements et al. 1997; Meza-Joya et al. 2013; Yadav et al. 2013), but relationships between genetic damage on blood cells with hepatic metabolic substances are poorly studied. In addition, use of hemosiderin and lipofuscin as morphological biomarkers of pesticide contamination is not known, but the use of melanin has been described due to its protective role. Other studies demonstrate that melanin is a good indicator of environmental stressors (Santos et al. 2014), contamination with bacteria (Franco-Belussi et al. 2013), and is importance as a marker of external effects. In this context, we consider interesting to evaluate the relationship between cytotoxic damage on blood cells and response of pigments on MMCs responsible for hemocateresis.

MMCs and their associated pigments (melanin, lipofuscin, and hemosiderin) are important in catabolic processes against oxidative damage and in the immune response triggered after herbicide exposure. As Coulliard and Hodson (1996) pointed
Table 1 Frequencies of micronuclei (MNs) and other nuclear abnormalities in peripheral blood erythrocytes of L. latinasus

\begin{tabular}{|c|c|c|c|c|c|}
\hline \multirow{2}{*}{$\begin{array}{l}\text { Exposure } \\
(\mu \mathrm{g} / \mathrm{g} \text { GLY) }\end{array}$} & \multirow[t]{2}{*}{ No. of cells } & \multirow[t]{2}{*}{$\mathrm{MNs} \pm \mathrm{SE}$} & \multicolumn{3}{|c|}{ Other nuclear abnormalities } \\
\hline & & & $\mathrm{NN} \pm \mathrm{SE}$ & $\mathrm{BL}$ nuclei $\pm \mathrm{SE}$ & $\mathrm{EPs} \pm \mathrm{SE}$ \\
\hline 0 & 5275 & $0.58 \pm 0.4$ & $0.56 \pm 0.2$ & $1.31 \pm 0.5$ & $1.71 \pm 1.4$ \\
\hline 100 & 4228 & $2.59 \pm 0.8^{*}$ & $0.00 \pm 0.0$ & $2.62 \pm 0.3$ & $0.48 \pm 1.0$ \\
\hline 1000 & 4115 & $1.72 \pm 0.5^{*}$ & $0.00 \pm 0.0$ & $2.08 \pm 0.9$ & $1.46 \pm 0.8$ \\
\hline 10,000 & 4382 & $2.81 \pm 0.9 *$ & $0.22 \pm 0.2$ & $0.71 \pm 0.5$ & $4.66 \pm 1.5^{*}$ \\
\hline
\end{tabular}

$N=5$ per treatment

*Showing significant differences with respect to control values 
out, an induced proliferation of MMCs may cause oxidative damage of cellular membranes, increased rate of cellular death, and accumulation of lipofuscin within MMCs. Other studies have reported an increase in the number of MMCs in organisms exposed to low levels of pollutants, which has been ascribed to the capacity of the cellular deference system to remove debris by increased phagocytic activity, with the consequent increase in MMCs (Agius and Roberts 2003). Our results from this study are congruent with those of Mela et al. $(2007,2012,2013)$ who observed degenerative necrotic conditions in the liver when exposed to high concentrations of a pollutant, and a predominant phagocytic activity of MMCs at low concentrations. Likewise, Brodkin et al. (2007) exposed Rana pipiens to low concentrations of the herbicide atrazine there is an increase on phagocytic activity. Moreover, the increment in MMCs activity by GLY exposure could be associated with a detoxification, an oxidative damage of the liver and increasing the recruitment and activation of defense cells as mentioned some authors for fish (Sebrenski da Silva et al. 2012; Mela et al. 2013) and as potential indicator of overall fish health (Pacheco and Santos 2002; Agius and Roberts 2003; Pascoli et al. 2011; Silva de Assis et al. 2013). In particular, morphological changes in liver MMCs of anurans and an impaired immunological function, have been used as biomarkers for the effects of sewage effluents and Escherichia coli contamination (Franco-Belussi et al. 2013); and temperature variations (Santos et al. 2014). Regardless, the effects of pesticides on liver MMCs of anurans were unknown, until this study. In this context, we propose the use of MMCs as morphological responses for the exposure to environmental chemicals, and as potential indicator of overall anuran health (Wolke et al. 1995; Agius and Roberts 2003).

Results from this study constitute the first report evaluating the systemic effects of a pesticide on an adult anuran. Since this is the first study of adult frogs, intra-abdominal inoculation route was chosen since animals do not possess predominant aquatic habits, so as tadpoles. Thus, this route of administration was important to ensure that the actual concentration reached the animal's body. Despite this, highest concentration of GLY in water was $162 \mu \mathrm{g} \mathrm{L}^{-1}$ in Canada (Feng et al. 1990) and $8.7 \mu \mathrm{g} \mathrm{L}^{-1}$ in midwestern states of USA (Scribner et al. 2003; USGS 2015); but in Argentina, with extensive agricultural practices and use of herbicides, highest concentrations of GLY was found and its metabolites with highest values of $1.84 \mathrm{mg} \mathrm{kg}^{-1}$ in soils (Peruzzo et al. 2008; Aparicio et al. 2013) and $560 \mu \mathrm{g} \mathrm{L}^{-1}$ in water surfaces (Peruzzo et al. 2008). In addition, according to WHO (1994) and safety data sheets formulations with GLY, the application of GLY are approximately between 0.3 and $5.8 \mathrm{~kg}$ a.i./ha being dependent on the type of use. In this context, and considering that L. latinasus makes its caves in soils and placed their nests with eggs, when specific events occurred like direct application, drainage ditches, or accidental discharge, this anuran populations could be exposed accidentally and be affected by GLY herbicide to highest range of concentrations.

On the other hand, this is the first study that evaluates effects of pesticides on MMCs pigments on anurans adults. In agreement with Fenoglio et al. (2005), Loumbourdis (2007), and Mela et al. $(2007,2012)$, we suggest that future research should focus on a better understanding of the role of MMCs in the detoxification of environmental pollutants and their role in antioxidant non-enzymatic systems and immune response. In other words, the responses of pigments on MMC liver could be used as morphological responses of immune toxicity and associated with degenerative necrotic conditions. It is unfortunate that there are only few studies focusing on the role of MMCs in anurans and other amphibians, despite these being recognized as good bioindicators organisms.

\section{Conclusion}

In sum, this study contributes to the understanding of the systemic effects of GLY in anuran. From these results, we suggest further studies using the responses of hepatic pigmentary system as morphological responses of pesticides on liver tissue. Morphological effects are important because they show structural effects in tissues that can be related with physiological functions. This study evaluated for the first time the action of chemicals stressor in liver MMCs of adult anuran, demonstrating the effects of GLY on the three pigmentary substances present in the MMCs (e.g., melanin, hemosiderin, and lipofuscin). Although the chemical was administered via intraperitoneal injection, which is not representative of normal field exposure, it provides a means of ensuring precise dosages that affects hepatic tissue. Moreover, our studies contributed to understanding effects of this herbicide an acute exposure of native anurans to a widely used herbicide.

Acknowledgments We are grateful to Gabriela Baroni Leite for helping with the histological procedures, Dr. Fernando Ferrari for help in statistical analysis, and GLEBA S.A. for providing pure glyphosate. This study was supported by CONICET (PIP 0723), FAPESP (Process 2013/02067-5), and CNPq (Grant 306123/2012-6). JMPI was supported by Universidad Nacional de San Luis (Res. No. 109/11 CS), while LFB was supported by a post-doctoral fellowship (FAPESP 2014/00946-4).

\section{References}

Agius C (1981) Preliminary studies on the ontogeny of the melanomacrophages of teleost hematopoetic tissues and agerelated changes. Dev Comp Immunol 5:597-606

Agius C, Roberts RJ (2003) Melano-macrophage centres and their role in fish pathology. J Fish Biol 26:499-509

Annett R, Habibi HR, Hontela A (2014) Impact of glyphosate and glyphosate-based herbicides on the freshwater environment. J Appl Toxicol 34:458-479 
Aparicio VC, De Gerónimo E, Marino D, Primost J, Carriquiriborde P, Costa JL (2013) Environmental fate of glyphosate and aminomethylphosphonic acid in surface waters and soil of agricultural basins. Chemosphere 93:1866-1873

Arregui MC, Lenardón A, Sanchez D, Maitre MI, Scotta R, Enrique S (2004) Monitoring glyphosate residues in transgenic glyphosateresistant soybean. Pest Manag Sci 60:163-166

Azqueta A, Shaposhnikov S, Collins AR (2009) DNA oxidation: investigating its key role in environmental mutagenesis with the comet assay. Mutat Res Genet Toxicol Environ Mutagen 674:101-108

Barni S, Bertone V, Croce AC, Bottiroli G, Bernini F, Gerzeli G (1999) Increased liver pigmentation during natural hibernation in some amphibians. J Anat 195:19-25

Blaustein AR, Wake DB (1990) Declining amphibian populations: a global phenomenon? Trends Ecol Evol 5:203-204

Blaustein AR, Wake DB, Sousa WP (1994) Amphibian declines: judging stability, persistence, and susceptibility of populations to local and global extinctions. Conserv Biol 8:60-71

Blaustein AR, Romansic JM, Kiesecker JM, Hatch AC (2003) Ultraviolet radiation, toxic chemicals and amphibian population declines. Divers Distrib 9:123-140

Bosch B, Mañas F, Gorla N, Aiassa D (2011) Micronucleus test in post metamorphic Odontophrynus cordobae and Rhinella arenarum (Amphibia: Anura) for environmental monitoring. J Toxicol Environ Health Sci 3:154-163

Brodkin MA, Madhoun H, Rameswaran M, Vatnick I (2007) Atrazine is an immune disruptor in adult northern leopard anurans (Rana pipiens). Environm Toxicol Chem 26:80-84

Bucke D, Vethaak AD, Lang AT (1992) Quantitative assessment of Melanomacrophage centres (MMCs) in dab Limanda limanda along a pollution transect in the German. Bight Mar Ecol Prog Ser 91:193196

Cakıc1 O (2015) Histopathologic changes in liver and kidney tissues induced by carbaryl in Bufotes variabilis (Anura: Bufonidae). Experim Toxicol Pathol 67:237-243

Campbell TW. 2015. Exotic animal hematology and cytology. John Wiley \& Sons, Hoboken, New Jersey

Carey C, Bryant CJ (1995) Possible interrelations among environmental toxicants, amphibian development, and decline of amphibian populations. Environ Health Persp 103:13-17

Christin MS, Ménarda L, Gendron AD, Rubyc S, Cyra D, Marcogliese DJ, Rollins-Smith L, Fournier M (2004) Effects of agricultural pesticides on the immune system of Xenopus laevis and Rana pipiens. Aquat Toxicol 67:33-43

Clements C, Ralph S, Petras M (1997) Genotoxicity of select herbicides in Rana catesbeiana tadpoles using the alkaline single-cell gel DNA electrophoresis (comet) assay. Environ Mol Mutagen 29(3):277_ 288

Couillard CM, Hodson PV (1996) Pigmented macrophage aggregates: a toxic response in fish exposed to bleached-kraft mill effluent? Environ Toxicol Chem 15:1844-1854

Davidson C, Shaffer BH, Jennings MR (2002) Spatial tests of the pesticide drift, habitat destruction, UV-B, and climate-change hypotheses for California amphibian declines. Conserv Biol 16:1588-1601

Fenech M (2007) Cytokinesis-block micronucleus cytome assay. Nat Protoc 2:1084-1104

Feng JC, Thompson DG, Reynolds PH (1990) Fate of glyphosate in a Canadian forest watershed. 1. Aquatic residues and off-target deposit assessment. J Agric Food Chem 38:1110-1118

Fenoglio C, Boncompagni E, Fasola M, Gandini C, Comizzoli S, Milanesi G, Barni S (2005) Effects of environmental pollution on the liver parenchymal cells and Kupffer-melanomacrophagic cells of the anuran Rana esculenta. Ecotoxicol Environ Saf 60:259-268

Franco-Belussi L, Castrucci AM, Oliveira C (2013) Responses of melanocytes and melanomacrophages of Eupemphix nattereri (Anura:
Leiuperidae) to $\mathrm{Nle}^{4}$, D-Phe ${ }^{7}-\alpha$-melanocyte stimulating hormone and lipopolysaccharides. Zool 116:316-324

Fuentes L, Moore LJ, Rodgers JH Jr, Bowerman WW, Yarrow GK, Chao WY (2011) Comparative toxicity of two glyphosate formulations (original formulation of Roundup ${ }^{\circledR}$ and Roundup Weathermax ${ }^{\circledR}$ ) to six north american larval anurans. Environ Toxicol Chem 30: 2756-2761

Giesy JP, Dobson S, Solomon KR (2000) Ecotoxicological risk assessment for Roundup herbicide. Rev Environ Contam Toxicol 167:35120

Gonçalves MW, Vieira TB, Maciel NM, Carvalho WF, Lima LSF, Gambale PG, Nomura F, Bastos RP, Silva DM (2014) Detecting genomic damages in the anuran Dendropsophus minutus: preserved versus perturbed areas. Environ Sci Poll Res. 22:3947-3954

Govindarajulu PP (2008) Literature review of impacts of glyphosate herbicide on amphibians: what risks can the silvicultural use of this herbicide pose for amphibians in B.C.? B.C. Ministry of Environment, Victoria, BC, Wildlife Report No R-28

Greulich K, Pflugmacher S (2003) Differences in susceptibility of various life stages of amphibians to pesticide exposure. Aquat Toxicol 65: 329-336

Güngördü A (2013) Comparative toxicity of methidathion and glyphosate on early life stages of three amphibian species: Pelophylax ridibundus, Pseudepidalea viridis, and Xenopus laevis. Aquat Toxicol 140-141:220-228

Gurushankara HP, Krishnamurthy SV, Vasudev V (2007) Morphological abnormalities in natural populations of common anurans inhabiting agroecosystems of central Western Ghats. Appl Herpetol 4:39-45

Harris ML, Bishop CA, Struger J, Ripley B, Bogart JP (1998) The functional integrity of northern leopard anuran (Rana pipiens) and green anuran (Rana clamitans) populations in orchard wetlands. II. Effects of pesticides and eutrophic conditions on early life stage development. Environ Toxicol Chem 17:1351-1363

Hedberg D, Wallin M (2010) Effects of Roundup and glyphosate formulations on intracellular transport, microtubules and actin filaments in Xenopus laevis melanophores. Toxicolin vitro 24:795-802

IUCN 2013. The IUCN red list of threatened Species. Version (2013) 2. http://www.iucnredlist.org. Downloaded on 21 November 2013

Jantawongsri K, Thammachoti P, Kitana J, Khonsue W, Kitana N (2013)Comparison herbicide utilization in paddy field alters immune response of the rice anuran Fejervarya limnocharis living in agricultural area at Nan province, Thailand. EHSM 2013, P-E-07: $1-6$

Jha AN (2008) Ecotoxicological applications and significance of the comet assay. Mutagenesis 23:207-221

Jones DK, Hammond JI, Relyea RA (2010) Roundup and amphibians: the importance of concentration, application time, and stratification. Environ Toxicol Chem 29:2016-2025

Jordanova M, Miteva N, Rocha E (2008) A qualitative and quantitative study of the hepatic pigmented macrophage aggregates during the breeding cycle of ohrid trout, Salmo letnica Kar. (Teloestei, Salmonidae). Microsc Res Tech 71:822-830

Kranz H (1989) Changes in splenic melano-macrophage centres of dab. Limanda limanda during and after infection with ulcer disease. Dis Aquat Organ 6:167-173

Lajmanovich RC, Attademo AM, Peltzer PM, Junges CM, Cabagna MC (2011) Toxicity of four herbicide formulations with glyphosate on Rhinella arenarum (Anura: Bufonidae) tadpoles: B-esterases and glutathione S-transferase inhibitors. Arch Environ Contam Toxicol 60:681-689

Lajmanovich RC, Cabagna-Zenklusen MC, Attademo AM, Junges CM, Peltzer PM, Bassó A, Lorenzatti E (2014) Induction of micronuclei and nuclear abnormalities in tadpoles of the common toad (Rhinella arenarum) treated with the herbicides Liberty ${ }^{\mathbb{B}}$ and glufosinate-ammonium. Mutat Res Genet Toxicol Environ Mutagen 769:7-12 
Loumbourdis NS (2007) Liver histopathologic alterations in the anuran Rana ridibunda from a small river of Northern Greece. Arch Environ Contam Toxicol 53:418-425

Loumbourdis NS, Vogiatzis AK (2002) Impact of cadmium on liver pigment system of the anuran Rana ridibunda. Ecotoxicol Environ Saf 53:52-58

Mann RM, Bidwell JR (1999) The toxicity of glyphosate and several glyphosate formulations to four species of Southwestern Australian anurans. Arch Environ Contam Toxicol 36:193-199

McComb BC, Curtis L, Chambers CL, Newton M, Bentson K (2008) Acute toxic hazard evaluations of glyphosate herbicide on terrestrial vertebrates of the Oregon Coast range. Env Sci Pollut Res 15:266272

Mela M, Randi MA, Ventura DF, Carvalho CE, Pelletier E, Ribeiro CAO (2007) Effects of dietary methylmercury on liver and kidney histology in the neotropical fish Hoplias malabaricus. Ecotoxicol Environ Saf 68:426-435

Mela M, Guiloski IC, Doria HB, Rabitto IS, Silva CA, Maraschi AC, Prodocimo V, FreireCA RMAF, Oliveira Ribeiro CA, Silva de Assis HC (2012) Risks of water borne copper exposure to a cultivated fresh water neotropical catfish (Rhamdia quelen). Ecotoxicol Environ Saf 88:108-116

Mela M, Guiloski IC, Doria HB, Randi MAF, Ribeiro CAO, Pereira L, Maraschi AC, Prodocimo V, Freire CA, Silva de Assis HC (2013) Effects of the herbicide atrazina in neotropical catfish (Rhamdia quelen). Ecotoxicol Environ Saf 93:13-21

Meza-Joya FL, Ramírez-Pinilla MP, Fuentes-Lorenzo JL (2013) Toxic, cytotoxic, and genotoxic effects of a glyphosate formulation (Roundup ${ }^{\circledR}$ SL-Cosmoflux ${ }^{\circledR} 411 \mathrm{~F}$ ) in the direct-developing anuran Eleutherodactylus johnstonei. Environ Mol Mutag 54:362-373

Moore LJ, Fuentes L, Rodgers JJH, Bowerman WW, Yarrow GK, Chao WY, Bridges WC Jr (2012) Relative toxicity of the components of the original formulation of roundups to five North American anurans. Ecotoxicol Environ Saf 78:128-133

National Research Council (US) Committee for the update of the guide for the care and use of laboratory animals. Guide for the care and use of laboratory animals. 8th edition. Washington (DC): National Academies Press (US) (2011) Available from: http://www.ncbi. nlm.nih.gov/books/NBK54050/

OECD (2007) .In vitro micronucleus test. OECD guidelines for the testing of chemicals, organization for economic co-operation and development (OECD), Paris.

Pacheco M, Santos MA (2002) Biotransformation, genotoxic, and histopathological effects of environmental contaminants in European eel (Anguilla anguilla L.). Ecotoxicol and Environ Saf 53:331-347

Pascoli F, Negrato E, Di Giancamillo A, Bertotto D, Domeneghini C, Simontacchi C, Mutinelli F, Radaelli G (2011) Evaluation of oxidative stress biomarkers in Zosterisessor ophiocephalus from the Venice Lagoon, Italy. Aquat Toxicol 101:512-520

Paunescu A, Ponepal CM, Drghici O, Marinescu AG (2010) Liver histopathologic alterations in the frog Rana (Pelophylax) Ridibunda induce by the action of reldan 40EC insecticide. An UO Fasc Biol 17: 166-169

Pérez-Iglesias JM, de Arcaute CR, Nikoloff N, Dury L, Soloneski S, Natale S, Larramendy ML (2014) The genotoxic effects of the imidacloprid-based insecticide formulation Glacoxan Imida on Montevideo tree frog Hypsiboas pulchellus tadpoles (Anura, Hylidae). Ecotoxicol Environ Saf 104:120-126

Peruzzo P, Porta A, Ronco AE (2008) Levels of glyphosate in surface waters, sediments and soils associated with direct sowing soybean cultivation in north pampasic region of Argentina. Environ Pollut 156:61-66

Pickford GW (1953) Fish endocrinology. A study of the hypophysectomized male killifish, Fundulus heteroclitus (L.). Bull Bingham Oceanogr Coll 14:5-41
Reboratti C (2010) Un mar de soja: la nueva agricultura en Argentina y sus consecuencias. Rev Geog Norte Grande 45:63-76

Relyea RA, Jones DK (2009) The toxicity of Roundup Original Max ${ }^{\circledR}$ to 13 species of larval amphibians. Environ Toxicol Chem 28:2004 2008

Relyea RA, Schoeppner NM, Hoverman JT (2005) Pesticides and amphibians: the importance of community context. Ecolog Appl 15: $1125-1134$

Rohr JR, Crumrine PW (2005) Effects of an herbicide and an insecticide on pond community structure and processes. Ecolog Appl 15:11351147

Rozanowska M, Sarna T, Land EJ, Truscott TG (1999) Free radical scavenging properties of melanin interaction of eu-and pheomelanin models with reducing and oxidizing radicals. Free Radic Biol Med 26:518-525

Rund CR, Christiansen JL, Johnson JC (1998) In vitro culture of melanomacrophages from the spleen and liver of turtles: comments on melanomacrophage morphology. Pigm Cell Res 11:114-119

Santos LRS, Franco-Belussi LF, Zieri R, Borges RE, Oliveira C (2014) Effects of thermal stress on hepatic melanomacrophages of Eupemphix nattereri (Anura). Anat Rec 297:864-875

Scribner EA, Battaglin WA, Dietze JE, Thurman EM (2003) Reconnaissance data for glyphosate, other selected herbicides, their degradation products, and antibiotics in 51 streams in nine Midwestern States, 2002: U.S. Geological Survey Open-File Report 03-217, $101 \mathrm{p}$.

Sebrenski da Silva G, Filipak Neto F, Silva de Assis HC, Bastos WR, Oliveira Ribeiro CA (2012) Potential risks of natural mercury levels to wild predator fish in an Amazon reservoir. Environ Monit Assess 184:4815-4827

Silva de Assis HC, Silva CA, Oba ET, Pamplona JH, Mela M, Doria HB, Guiloski IC, Ramsdorf W, Cestari MM (2013) Hematologic and hepatic responses of the freshwater fish Hoplias malabaricus after saxitoxin exposure. Toxicon 66:25-30

Sparling DW, Linder G, Bishop CA, Krest SK (2010) Ecotoxicology of amphibians and reptiles. CRC Press. SETAC Books, Boca Raton, Florida. Second Edition. pp. 916.

Stebbins RC, Cohen NW (1995) A natural history of amphibians. Princeton Univ. Press, Princeton, New Jersey, p 368

Struger J, Thompson D, Staznik B, Martin P, McDaniel T, Marvin C (2008) Occurrence of glyphosate in surface waters of southern Ontario. Bull Environ Contam Toxicol 80:378-384

U.S. Department of the Interior | U.S. Geological Survey. URL: http:// toxics.usgs.gov/highlights/glyphosate02.html. Page Last Modified: Tuesday, 04-Aug-2015.

Vaira M, Akmentins M, Attademo A, Baldo D, Barrasso D, Barrionuevo S, Basso N, Blotto B, Cairo S, Cajade R, Céspedez J, Corbalán V, Chilote P, Duré M, Falcione C, Ferraro D, Gutierrez F, Junges P, Lajmanovich R, Lescano J, Marangoni F, Martinazzo L, Marti L, Moreno L, Natale G, Pérez Iglesias J, Peltzer P, Quiroga L, Rosset S, Sanabria E, Sánchez P, Schaefer E, Úbeda C, Zaracho V (2012) Categorización del estado de conservación de los Anfibios de la República Argentina. Cuad Herpetol 26:131-159

Van der Oost R, Beyer J, Vermeulen NP (2003) Fish bioaccumulation and biomarkers in environmental risk assessment: a review. Environ Toxicol Pharmacol 13:57-149

Wagner N, Reichenbecher W, Teichmann H, Tappeser B, Lötters S (2013) Questions concerning the potential impact of glyphosate-based herbicides on amphibians. Environ Toxicol Chem 32:1688-1700

Williams GM, Kroes M, Munro IC (2000) Safety evaluation and risk assessment of the herbicide Roundup and its active ingredient, glyphosate, for humans. Regulatory Toxicol Pharmacol 31:117-165

Wolke RE, George CJ, Blazer VS (1995) Pigmented macrophage accumulations (MMC; PMB): possible monitors of fish health. In: Parasitology and pathology of the world oceans (ed. By W.J. 
Hargis). NOAA Technical Report, NMFS 25. National Marine Fishery Service, Washington, DC, pp 27-33

World Health Organization (WHO) (1994) Environmental health criteria: Glyphosate. Geneva, 159: p 177

Yadav SS, Giri S, Singha U, Boro F, Giri A (2013) Toxic and genotoxic effects of Roundup on tadpoles of the Indian skittering frog (Euflictis cyanophlyctis) in the presence and absence of predator stress. Aquat Toxicol 15:132-133

Zar JH (2010) Biostatistical Analysis, 5th edn. Prentice Hall, NewJersey, p 994 